University of Missouri-Kansas City School of Law

UMKC School of Law Institutional Repository

\title{
Branded Drug Companies Are Successfully Asserting the Doctrine of Equivalents in Hatch-Waxman Litigation
}

Christopher M. Holman

University of Missouri - Kansas City, School of Law

Follow this and additional works at: https://irlaw.umkc.edu/faculty_works

\section{Recommended Citation}

Christopher M. Holman, Branded Drug Companies Are Successfully Asserting the Doctrine of Equivalents in Hatch-Waxman Litigation, 40 Biotechnology Law Report 72 (2021).

Available at: https://irlaw.umkc.edu/faculty_works/222 
PRE-PRINT VERSION (For print version see Christopher M. Holman, Branded Drug

Companies Are Successfully Asserting the Doctrine of Equivalents in Hatch-Waxman Litigation, 40 BioteCHNOLOGY LAW REPORT 72 (2021)).

\title{
Branded Drug Companies Are Successfully Asserting the Doctrine of Equivalents in Hatch-Waxman Litigation
}

\author{
Christopher M. Holman*
}

\begin{abstract}
This article reports the results of a study analyzing every Federal Circuit decision the author could find dating back to 2005 that applies the doctrine equivalents (DOE) in the context of pharmaceutical patent litigation, and in particular infringement lawsuits brought against Abbreviated New Drug Application (ANDA) applicants by branded drug companies under the HatchWaxman Act. The results of this study show that pharmaceutical innovators were prevailing against would-be generic competitors under the DOE both prior to, and subsequent to, a 2007 article by Professors Lemley and Allison describing the demise of the doctrine equivalents, but that patentees' success rate has improved markedly in recent years. This article is a follow-up to another Holman Report I published last year that focused on application of the DOE to biomolecule claim limitation, Ajinomoto v. ITC, the Doctrine of Equivalents, and Biomolecule Claim Limitations at the Federal Circuit.
\end{abstract}

The doctrine of equivalents is judge-made law in the U.S. that, under certain circumstances, allows a court to find a party liable for patent infringement even though the accused product or process does not literally infringe an asserted patent claim. Prior to 2000, critics were complaining that courts were applying the doctrine in an overly permissive, i.e., patenteefriendly manner that was essentially allowing the exception to swallow the rule. ${ }^{1}$ Some argued that the doctrine "lack[ed] a coherent vision," others that it had become the most controversial doctrine in all of patent law. ${ }^{2}$

\footnotetext{
${ }^{*}$ Christopher M. Holman, Professor of Law, University of Missouri-Kansas City School of Law; Senior Fellow, Center for the Protection of Intellectual Property, Antonin Scalia Law School, George Mason University; and Executive Editor, Biotechnology Law Report.

${ }^{1}$ John R. Allison and Mark A. Lemley, The (Unnoticed) Demise of the Doctrine of Equivalents, 59 Stan. L. Rev. 955 (2007).

${ }^{2} I d$. (citing sources).
} 
In 2000, the Federal Circuit substantially raised the bar for patent owners seeking to prove infringement under the doctrine equivalents in Festo I, an en banc decision that established an absolute bar against applying the doctrine equivalents to a claim limitation in cases in which the patentee had narrowed that limitation during prosecution of the patent. ${ }^{3}$ This was a substantial doctrinal shift, given that narrowing claim amendments are very common in patent prosecution. As a practical matter, Festo I severely undermined the doctrine and its purpose, which is to prevent "fraud on the patent" by "unscrupulous copyists" that seek to evade liability through insubstantial changes to the invention that circumvent the literal language of the claims. Two years later, the Supreme Court significantly tempered the draconian absolute bar of Festo I, replacing it (in Festo II) with a rebuttable presumption that a narrowing claim amendment surrenders all equivalents, and identifying specific circumstances under which the presumption might be overcome, i.e., when the alleged equivalent was unforeseeable at the time of the amendment, or only tangentially related to whatever it was that prompted the narrowing amendment. ${ }^{4}$

Although Festo II attenuated the harshness of the presumption originally set forth in Festo I, it was still viewed as a substantial heightening of the bar compared to pre-2000 law, rendering it less likely that a patent owner would be able to prevail under the doctrine. In a 2007 law review article, The (Unnoticed) Demise of the Doctrine of Equivalents, Professors Lemley and Allison reported the findings of their empirical study of doctrine equivalent decisions before and after the Festo decisions. They concluded that, surprisingly, the Festo decisions had "surprisingly little effect on the actual outcome of doctrine of equivalents cases, and even less effect on the subset of cases dealing directly with prosecution history estoppel."5 Even more significantly, they found that, even under the relatively permissive doctrine of equivalents rules in place before 2000, "the doctrine of equivalents was already near death by the late 1990s," and that district courts are more likely to reject doctrine of equivalents claims today than ever before."

Lemley and Allison's conclusion, that the doctrine of equivalents was near death in 2000 and in a state of continuing decline, was echoed in a 2010 article by David Schwartz entitled Explaining the Demise of the Doctrine of Equivalents. Professor Schwartz proposed that the "demise of the doctrine of equivalents" was the consequence of two complementary forces the he referred to as "doctrinal reallocation" and "doctrinal displacement."

In a December 2020 blogpost, Kevin Noonan (of Patent Docs) commented that "[a]fter more than two decades of being the red-headed stepchild of patent infringement before the Federal Circuit, infringement under the doctrine of equivalents has made a dramatic comeback in the past few years, the Court affirming plaintiffs asserting their patents under the doctrine six times (versus denying DOE infringement on the basis of prosecution history estoppel twice, on the basis of the dedication-disclaimer estoppel twice, and finding no equivalents twice)." 6 In particular, he pointed to two decisions, both involving the same patent, in which the Federal

${ }^{3}$ Festo Corp. v. Shoketsu Kinzoku Kogyo Kabushiki Co., 234 F.3d 558 (Fed. Cir. 2000) (en banc).

${ }^{4}$ Festo Corp. v. Shoketsu Kinzoku Kogyo Kabushiki Co., 535 U.S. 722 (2002).

${ }^{5}$ Id.

${ }^{6}$ Kevin E. Noonan, Eli Lilly \& Co. v. Apotex, Inc. (Fed. Cir. 2020), Patent Docs (December 27, 2020), available at https://www.patentdocs.org/2020/12/eli-lilly-co-V-apotex-inc-fed-cir-2020.html (last visited February 6, 2021). 
Circuit affirmed a finding of infringement under the doctrine of equivalents, Eli Lilly $\&$ Co. $v$. Hospira, Inc. and Eli Lilly \& Co. v. Apotex, Inc. (both discussed below).

I concur with Noonan's observation that in recent years the Federal Circuit has become more receptive to allegations of infringement under the doctrine equivalents. One notable example from 2019 that illustrates this point comes to mind. In Amgen v. Sandoz, an opinion written by long-tenured Federal Circuit Judge Alan Lourie, the judge stated that " $[\mathrm{t}]$ he doctrine of equivalents applies only in exceptional cases." 7 On a petition for rehearing, the panel granted rehearing "to the extent that" the "applies only in exceptional cases" language of the original decision was deleted from the original opinion. This correction of Judge Lourie's statement is consistent with my own observation that it is no longer an exceptional event when a patentee prevails under the doctrine of equivalents. ${ }^{8}$

In this article, I report the results of a study I conducted analyzing every Federal Circuit decision I could find dating back to 2005 that applies the doctrine equivalents (DOE) in the context of pharmaceutical patent litigation, and in particular infringement lawsuits brought against Abbreviated New Drug Application (ANDA) applicants by branded drug companies under the Hatch-Waxman Act. The results of this study show that pharmaceutical innovators were prevailing against would-be generic competitors under the DOE both prior to, and subsequent to, Lemley and Allison's article describing the demise of the doctrine equivalents, but that patentees' success rate has improved markedly in recent years. In the first section of this article, I summarize the results in a number of cases in which the patentee branded drug company prevailed under the DOE against an ANDA applicant. In the following section, I summarize decisions in which the Federal Circuit found a branded drug company likely to succeed in proving infringement under the DOE, in the context of the appeal of a preliminary injunction. The third section of the article summarize the cases I found in which an allegation of infringement under the DOE failed. This article is a follow-up to another Holman Report I published last year that focused on application of the DOE to biomolecule claim limitation, Ajinomoto v. ITC, the Doctrine of Equivalents, and Biomolecule Claim Limitations at the Federal Circuit. ${ }^{9}$

\section{Decisions finding infringement under the DOE}

In the following decisions, the Federal Circuit affirmed a finding that an Orange Book-listed patent would be infringed by an ANDA applicant's proposed generic product under the doctrine of equivalents.

Abraxis Bioscience, Inc. v. Mayne Pharma (2006)

In 1989 AstraZeneca launched DIPRIVAN as an original pharmaceutical composition used to induce and maintain general anesthesia and sedation in patients. DIPRIVAN consists of an injectible oil-in-water emulsion containing propofol, or 2,6-diisopropyl phenol, as its active

\footnotetext{
${ }^{7}$ Amgen Inc. v. Sandoz Inc., 923 F.3d 1023, 1029 (Fed. Cir.).

${ }^{8}$ Amgen Inc. v. Sandoz Inc., 776 F. App'x 707 (Fed. Cir. 2019).

${ }^{9}$ Christopher M. Holman, Ajinomoto v. ITC, the Doctrine of Equivalents, and Biomolecule Claim Limitations at the Federal Circuit, 39 Biotechnology Law Report 3 (2020).
} 
ingredient. In 1990, AstraZeneca became aware that patients using DIPRIVAN were suffering from postoperative infections linked to DIPRIVAN. AstraZeneca researchers sought to address the problem through the use of preservatives, but most of the preservatives they tested were found to be ineffective. Ultimately, the inventors of the patents at issue in the case discovered that one preservative in particular, disodium edetate, was unexpectedly effective in retarding microbial growth in the propofol formulation for at least twenty-four hours, without disrupting the oil-in-water emulsion. AstraZeneca subsequently developed an improved DIPRIVAN formulation consisting of edetate along with other ingredients present in the original formulation. In March 1995, the inventors applied for a patent on their improved DIPRIVAN formulation, ultimately resulting in the three patents at issue in the case, all of which share a common written description. The patents claim propofol formulations comprising "edetate."

In 1995, ESI (a generic drug company) learned of the reports of infection relating to original DIPRIVAN, and that AstraZeneca had reformulated its composition by adding an antimicrobial agent. ESI decided to develop a similar generic formulation. ${ }^{10}$ After reviewing AstraZeneca's '520 patent, scientists at ESI began screening antimicrobial agents in an effort to replace the edetate in the improved DIPRIVAN formulation with a different antimicrobial agent. They identified the calcium trisodium salt of diethylenetriaminepentaacetic acid (pentetate), which is also referred to as DTPA, based on a consideration of a number of factors, including that the "product must be approvable as an ANDA without clinical or safety studies ... [and] must match the reference product characteristics and stability profile" of AstraZeneca's improved formulation. They understood that since calcium trisodium DTPA is "structurally similar to edetate, product stability is predicted to be unaffected." Their studies showed that calcium trisodium DTPA produced the same characteristics and stability profile as improved DIPRIVAN, and ESI ultimately developed a generic propofol formulation employing calcium trisodium DTPA as the antimicrobial additive. ESI obtained a patent on its pharmaceutical composition.

AstraZeneca sued in a Hatch-Waxman action, and the district court found that the proposed generic product would infringe AstraZeneca's patents. In reaching this result, the district court construed the term "edetate" to mean "EDTA as well as compounds structurally related to EDTA regardless of how they are synthesized." Based on this claim construction, the district court found that calcium trisodium DTPA is in "edetate" because it is a "structural analog" of EDTA, and thus concluded that the claims would be infringed literally and/or under the doctrine equivalents by the proposed generic.

On appeal, the Federal Circuit found that the district court had misconstrued "edetate," and that the proper construction of the term is "EDTA and derivatives of EDTA, such as salts, but not including structural analogs." 11 The court further found that, under the proper interpretation of the term, calcium trisodium DTPA is not an edetate, and for that reason none of the asserted claims are literally infringed. But the court then proceeded to affirm the district court's finding

\footnotetext{
${ }^{10}$ ESI filed the Abbreviated New Drug Application (“ANDA") for the generic propofol emulsion, and later assigned it to the defendant Mayne.

${ }^{11}$ Abraxis Bioscience, Inc. v. Mayne Pharma (USA) Inc., 467 F.3d 1370 (Fed. Cir. 2006).
} 
of infringement under the doctrine of equivalents, which was based on the lower court's finding that the differences existing between calcium trisodium DTPA and edetate were insubstantial.

In reaching this conclusion, the district court performed a function-way-result analysis. The court identified the "function" of edetate as "retard[ing] microbial growth in propofol oil-in-water emulsions." The court then defined the "way" that edetate worked as by metal ion chelation, and found that the "result" achieved was "retard[ing] microbial growth to the extent required by the microbiological test set forth in the claims." The court found that calcium trisodium DTPA similarly retards microbial growth in an oil-in-water emulsion by metal ion chelation to retard the growth of the microorganisms to the extent required by a test set forth in the patent claims.

On appeal, Mayne argued that the district court clearly erred in defining the "way" as metal ion chelation, and that the proper definition of "way" is a narrower one, i.e., one that incorporates the specific metal ions that are chelated, the strength of the bonds that are formed during chelation, and the stability constants. But the Federal Circuit rejected that argument, concluding that the district court had not clearly erred in defining "way" as metal ion chelation and in finding that that is the "way" in which calcium trisodium DTPA functions as an antimicrobial agent, pointing out that Mayne itself had argued to the FDA that calcium trisodium DTPA is an effective antimicrobial agent in its generic propofol formulation because "of its ability to chelate divalent metal ions."

Mayne also argued that the lack of known interchangeability between edetate and DTPA as an antimicrobial agent precluded a finding of infringement under the doctrine of equivalents. Mayne pointed to the fact that it was able to receive a patent on its own DTPA formulation as evidence of the lack of known interchangeability. However, the Federal Circuit rejected this argument, finding that, "[i]n fact, the absence of known interchangeability underscores that the patent applicant had no reason to foresee and claim DTPA in this combination."

The Federal Circuit concluded that the district court's conclusion that Mayne's generic propofol formulation infringes the patents in suit under the doctrine of equivalents was not clearly erroneous, and that, indeed, the conclusion was consistent with the findings made by the district court that calcium trisodium DTPA was specifically chosen for the generic propofol formulation because of its structural similarities to edetate and the likelihood that it would match the product characteristics and stability profile of Abraxis' improved DIPRIVAN formulation.

Pozen Inc. v. Par Pharm., Inc. (2012)

Pozen, in partnership with GlaxoSmithKline ("GSK"), markets a combination of sumatriptan and naproxen called Treximet ${ }^{\circledR}$, used in the treatment of migraines. ${ }^{12}$ The ' 183 patent claims a multilayer pharmaceutical tablet with a triptan, such as sumatriptan, and a NSAID in separate layers that dissolve independently. Pozen sued ANDA applicants Par and DRL under HatchWaxman. The district court held that under the doctrine of equivalents Par and DRL's ANDA products infringe claim 2 of the ' 183 patent, which is dependent on claim 1, and reads:

\footnotetext{
${ }^{12}$ Pozen Inc. v. Par Pharm., Inc., 696 F.3d 1151 (Fed. Cir. 2012).
} 


\section{PRE-PRINT VERSION}

1. A multilayer pharmaceutical tablet comprising naproxen and a triptan and, wherein:

a) substantially all of said triptan is in a first layer of said tablet and substantially all of said naproxen is in a second, separate layer; and

b)said first layer and said second layer are in a side by side arrangement such that the dissolution of said naproxen occurs independently of said triptan.

2. The tablet of claim 1 , wherein said naproxen is in the form of naproxen sodium between 200 and $600 \mathrm{mg}$.

The parties agreed that the claim term "dissolution of said naproxen occurs independently of said triptan" means "[d]issolution of naproxen ... and triptan from the multilayer tablet ... occurs in the same amount of time $\pm 10 \%$ as when the same amount of naproxen ... and triptan are given separately." The ANDA filers argued that the district court should have required proof that the active agents in their generic products achieved dissolution in about the same time $( \pm 10 \%)$ it would take for either of the active agents to achieve dissolution when taken alone, and that the record evidence had not proven this. However, relying upon the generic companies' FDA filings and expert testimony presented at trial, the district court found that the ANDA products perform the same function in the same way to achieve the same results and therefore satisfy the independent dissolution limitation under the doctrine of equivalents. For example Pozen's expert noted that Par's ANDA product was specifically formulated to achieve complete and independent dissolution, and in its ANDA, Par represented to the FDA that the sumatriptan and naproxen in its ANDA product dissolves completely and independently from each other. Similarly, DRL's ANDA product achieves independent dissolution "by the way it formulates and manufactures the tablets."

The Federal Circuit affirmed, finding that

Although there was no direct evidence comparing the rate of dissolution of the ANDA products to that of the agents individually, no such actual comparison was necessary. Under the doctrine of equivalents analysis Pozen need only show that the ANDA products performed the same function in the same way to achieve the same result as the claimed elements of the '183 patent. Par and DRL provided expert testimony to show that the sumatriptan dissolves completely and independently from the naproxen and that the naproxen dissolves completely and independently from the sumatriptan in their ANDA products. Also, there is probative evidence from Par's ANDA and comparison of DRL's ANDA products dissolution profile showing that their sumatriptan and naproxen dissolve completely and independently from another. As a result, Appellants offer no basis for setting aside the district court's finding. Indeed, there is sufficient evidence showing that logically if the agents dissolve in the same way they would if the other agent was not present, their dissolution takes the same amount of time it would taken when given separately. Thus, the district court did not clearly err in relying on Pozen's expert testimony and concluding that Appellants' ANDA 
products meet the "independent dissolution" limitation as recited in claim 1 of the '183 patent under the doctrine of equivalents. ${ }^{13}$

The district court construed the phrase "substantially all of said triptan is in a first layer of said tablet and substantially all of said naproxen is in a second, separate layer" as meaning "[a]t least $90 \%$, and preferably greater than $95 \%$, of the total triptan present in the tablet is included within one distinct layer and at least $90 \%$, and preferably greater than $95 \%$, of the naproxen present in the tablet is included within a second distinct layer."

It was undisputed that the first layer of Par's ANDA tablet "contains $100 \%$ of the tablet's sumatriptan, along with $15 \%$ of the tablet's naproxen, with the remaining $85 \%$ of the naproxen in the second layer. DRL's ANDA tablet has $100 \%$ of the tablet's naproxen and $15 \%$ of the tablet's sumatriptan in the first layer, with the remaining $85 \%$ of the sumatriptan in the second layer."

Defendant Par argued that the district court improperly treated the claim term "substantially all" as a precise quantity entitled to the doctrine of equivalents, when in fact it is really a "fuzzy" quantitative limitation not entitled to equivalents. Par asserted that the word "substantially" was used to capture values lower than $100 \%$, and indeed the district court had construed the term to include any amount as low as $90 \%$. As such, Par argued that Pozen should not be able to reach below $90 \%$ "to encompass equivalents of equivalents."

Defendant DRL argued that the district court had erred in granting Pozen a range of equivalency for the '183 patent beyond the scope of equivalency determined through claim construction. DRL asserted that in the cases cited by the district court, the degree to which the accused product fell outside the specifically claimed range was miniscule in comparison to the amount their ANDA product falls outside of the claimed range. In DRLs product, sumatriptan only makes up $85 \%$ of one layer; $5 \%$ less than the minimum $90 \%$ set forth in the construction of the term "substantially all."

The Federal Circuit acknowledged its own precedent supporting the proposition that where "a patentee has brought what would otherwise be equivalents of a limitation into the literal scope of the claim, the doctrine of equivalents is unavailable to further broaden the scope of the claim."14 The court found that in this case, however, although the claim language itself is a qualitative measure, the claim construction pulls directly from the specification to give the term "substantially all" a quantitative definition, specifically, "at least $90 \%$, and preferably greater than 95\%," and that the Federal Circuit has previously concluded that the doctrine of equivalents is not foreclosed with respect to claimed ranges. In this case, Pozen never stated that "at least $90 \%$, and preferably greater than $95 \%$ " should be an absolute floor, and the court concluded that under the doctrine of equivalents a tablet layer with $85 \%$ of the agent can be fairly characterized as an insubstantial change from a tablet layer with $90 \%$ of the agent.

With respect to the district court's analysis of infringement of the "substantially all" limitation, the parties' experts agreed that the function of the claimed multilayer tablet was to have

${ }^{13} I d$.

${ }^{14} I d$. 
"separate, distinct layers of sumatriptan and naproxen. The way in which this function is achieved is by formulating the sumatriptan and naproxen in different manners to create physical barriers. The result is that substantially naproxen is separated from the [sumatriptan], thereby providing independent dissolution."

The district court found that Par's ANDA product performs essentially the same function, by segregating the naproxen and sumatriptan into two layers. This is achieved by formulating them differently, specifically, by using a polymer binder to form $15 \%$ of the naproxen into granules which are added to the sumatriptan layer. The result is that one layer has $100 \%$ of the sumatriptan with $15 \%$ of the naproxen, and another layer has the remaining $85 \%$ of the naproxen, substantially all separated and segregated into two layers. Therefore, the district court determined, Par's ANDA product performs the same function, in the same way, and achieves the same result, and satisfies all of the limitations of the ' 183 patent under the doctrine of equivalents.

The district court also found that DRL's ANDA product performs the same function of achieving separate, distinct layers by segregating the triptan and naproxen. $I d$. This is achieved by granulating $15 \%$ of the sumatriptan with a polymer binder and then spraying it on the naproxen which has been granulated with a polymer binder as well; the remaining $85 \%$ of the sumatriptan forms the other layer. "Thus, substantially all the triptan is segregated and separated into the equivalent of a first distinct layer, in an equivalent side-by-side arrangement, and this achieves the result of independent dissolution." Therefore, the district court determined, DRL's ANDA product performs the same function, in the same way, and achieves the same result, and satisfies all of the limitations of the '183 patent under the doctrine of equivalents.

The generic defendants argued that their ANDA products do not achieve separate distinct layers because one of the layers has both agents. However, their products contain a bilayer tablet, with $100 \%$ of one agent in one layer, and $85 \%$ of the other agent in the other layer. The Federal Circuit agreed with the district court that this structure is insubstantially different from a bilayer tablet with $90 \%$ of the total therapeutic agent present in the tablet included in a single layer. Based on the evidence, the district court had not clearly err in finding that Par's ANDA products and DRL's ANDA products met the "substantially all" limitation of the '183 patent under the doctrine of equivalents.

Writing in dissent, Judge Clevenger argued that

Even if the equivalent layer notion has merit, it still cannot be disconnected from the language of the claim. The equivalent layer would, in any event, have to be the equivalent of a more or less pure layer, i.e., one with at least $90 \%$ and preferably $95 \%$ of the required ingredient in it. How can a layer with only $85 \%$ of the necessary ingredient in it be an equivalent of a layer with at least $90 \%$ and preferably $95 \%$ of the required ingredient in it?

$\cdots$

In my view, the District Court erred by not asking itself if under claim 2 a layer, viewed from the outside or from the inside, can be equivalent if is numerically 
nonequivalent. It cannot. The majority states that "a reasonable person could determine that a tablet layer with $85 \%$ of the agent is within the scope of the doctrine of equivalents." Respectfully, I disagree.

As noted by Judge Clevenger in his dissent, the ANDA products were designed to avoid the claims" "substantially all” limitation.

\section{Cadence Pharm. Inc. v. Exela PharmSci Inc. (2015)}

Cadence Pharmaceuticals Inc. markets an injectable acetaminophen product, which is approved by the Food and Drug Administration ("FDA") and is distributed under the name Ofirmev®. ${ }^{15}$

The FDA's Approved Drug Products with Therapeutic Equivalence Evaluations (better known as the "Orange Book") lists the '218 patent in connection with Ofirmev®. One of the Orange Book listed patents, the '281 patent, claims a "method for preparing an aqueous solution [of acetaminophen], while preserving for a prolonged period, comprising de-oxygenation of the solution by bubbling with at least one inert gas and/or placing under vacuum, until the oxygen content is below $2 \mathrm{ppm}$...."

Exela filed an ANDA seeking FDA approval of a generic equivalent of Ofirmev ${ }^{\circledR}$, and Cadence sued for infringement of the patent. The generic company sought to avoid the patent claim by deoxygenating the water prior to dissolving acetaminophen in it. This did avoid literal infringement, because the claim, as interpreted by the district court, required deoxygenation of a solution that already comprises acetaminophen. Nonetheless, the district court found infringement under the doctrine equivalents. The district court found that the timing of the addition of the active ingredient did not matter and ruled that the differences between the claimed steps and Exela's method were insubstantial. The district court relied on the testimony of Cadence's expert, Dr. Orr, "that adding acetaminophen before or after the deoxygenation step would have no impact on the stability of the final product." Dr. Orr explained that this was so because "in both cases you're trying to deoxygenate your solution. In both cases, you're employing bubbling to do that. And the results that you achieve under this prolonged period ofof bubbling is still a solution of less than two parts per million."

On appeal, the Federal Circuit held that this testimony supported the district court's finding that changing the timing of the deoxygenation step was an insubstantial difference. ${ }^{16}$ The Federal Circuit further noted that the correctness of this conclusion was confirmed by "the district court's finding and Exela's accession that its formulation is, in fact, stable."

Exela further argued that deoxygenating after adding the active ingredient is the "antithesis" of deoxygenating before adding the active ingredient, and for that reason a finding of infringement under the doctrine of equivalents would impermissibly "vitiate" a claim limitation. The Federal Circuit rejected this argument, explaining that:

Exela fundamentally misunderstands the doctrine of claim vitiation. "Vitiation" is not an exception or threshold determination that forecloses resort to the doctrine of equivalents, but is instead a legal conclusion of a lack of equivalence based on

\footnotetext{
${ }^{15}$ Cadence Pharm. Inc. v. Exela PharmSci Inc., 780 F.3d 1364 (Fed. Cir. 2015).
}

${ }^{16}$ Cadence Pharm. Inc. v. Exela PharmSci Inc., 780 F.3d 1364 (Fed. Cir. 2015). 
the evidence presented and the theory of equivalence asserted. We have repeatedly reaffirmed this proposition. Characterizing an element of an accused product as the "antithesis" of a claimed element is also a conclusion that should not be used to overlook the factual analysis required to establish whether the differences between a claimed limitation and an accused structure or step are substantial vel non. The determination of equivalence depends not on labels like "vitiation" and "antithesis" but on the proper assessment of the language of the claimed limitation and the substantiality of whatever relevant differences may exist in the accused structure. ${ }^{17}$

\section{Intendis GMBH v. Glenmark Pharm. Inc., USA (2016)}

Bayer markets Finacea Gel, which contains azelaic acid as the therapeutically active ingredient in a concentration of $15 \%$ by weight and is indicated for the topical treatment of inflammatory papules and pustules of mild to moderate rosacea. ${ }^{18}$ Finacea Gel's inactive ingredients (excipients) include triglycerides and lecithin.

Glenmark submitted an ANDA seeking approval to market a generic version of Finacea Gel. Unlike Finacea Gel, the proposed generic product substituted isopropyl myristate for the claimed triglyceride and lecithin. Bayer sued for infringement of U.S. Patent No. 6,534,070 ("the '070 patent"). The asserted claims recite a composition that comprises, inter alia, azelaic acid, a triglyceride, and lecithin. The district court found infringement, based on its determination that the isopropyl myristate in Glenmark's generic product met the claims' triglyceride and lecithin limitations under the doctrine of equivalents, relying on the function-way-result test.

First, the court found that isopropyl myristate in Glenmark's generic product ("Glenmark's excipient") performs substantially the same function as the claimed excipients - namely, enhancing azelaic acid's penetration of the skin. It reasoned that several experts testified that the claimed excipients could act as penetration enhancers and that "nothing in the record" indicated they could not. It also reasoned that Glenmark's ANDA included repeated statements that both Glenmark's excipient and the claimed excipients function as penetration enhancers. It noted that Glenmark "should not be permitted to liken their product to the claimed composition to support their bid for FDA approval, yet avoid the consequences of such a comparison for purposes of infringement."

Second, the court found that Glenmark's excipient performed in substantially the same way as the claimed excipients - namely, by disrupting the lipids in the skin's outermost layer, known as the stratum corneum. It based its finding on testimony by various experts, as supported by scientific literature.

Third, the court found that Glenmark's excipient obtained substantially the same result as the claimed excipients - namely, a therapeutically effective azelaic acid composition that is able to penetrate the skin in order to deliver the active ingredient. It relied on data from the '070 patent, Glenmark's own patent application, a skin penetration study, and a clinical trial.

${ }^{17} I d$., (citations omitted).

${ }^{18}$ Intendis GMBH v. Glenmark Pharm. Inc., USA, 822 F.3d 1355 (Fed. Cir. 2016). 
The issue on appeal was whether the district court clearly erred when it determined that triglyceride and lecithin function as penetration enhancers in the claimed compounds. Glenmark argued that the district court erred in its finding regarding the function prong because Bayer failed to prove that the claimed excipients function as penetration enhancers in the claimed composition. According to Glenmark, the fact that the patent was silent as to whether lecithins or triglycerides function as penetration enhancers was fatal to a finding of infringement. The Federal Circuit disagreed, stating that " $[\mathrm{w}] \mathrm{e}$ have never held that a patent must spell out a claim element's function, way, and result in order for the doctrine of equivalents to apply as to that element. To the contrary, we have held that when the claims and specification of a patent are silent as to the result of a claim limitation, we should turn to the ordinary skilled artisan. ... The relevant inquiry is what the claim element's function in the claimed composition is to one of skill in the art, and a fact finder may rely on extrinsic evidence in making this factual determination." 19

In response to Glenmark's assertion that the district court erred in its determination that the claimed excipients function as penetration enhancers in light of the evidence of record, the Federal Circuit responded:

We see no clear error in this district court fact finding. Fatal to Glenmark's argument is its own ANDA submission to the FDA repeatedly referring to the claimed excipients (triglyceride and lecithin) as penetration enhancers. For example, Glenmark stated in its filing to the FDA that "[i]sopropyl myristate was selected as [a] penetration enhancer instead of lecithin and medium chain triglyceride" under the heading "Selection of penetration enhancer." Glenmark's repeated statements to the FDA that the claimed excipients function as penetration enhancers tend to show that one of skill in the art would understand the claimed excipients to function as penetration enhancers. We see no reason why a district court acting as a fact finder should ignore a party's representation to a federal regulatory body that is directly on point. Based on this record, the district court's finding regarding the function of the claimed excipients is not clearly erroneous.

In a strange turn of events, Glenmark argued at oral argument to this court that its statements in its FDA submissions about the claimed excipients (triglyceride and lecithin) functioning as penetration enhancers should be rejected and cannot be evidence to support the district court's finding. It argued that "lecithin and triglycerides are not known to the art as penetration enhancers" and that its representation to the FDA that they do function as penetration enhancers was a "guess" and "wrong." These seemingly extemporaneous arguments do not persuade us that there is clear error in the district court's decision that isopropyl myristate in Glenmark's generic product and the claimed triglyceride and lecithin perform substantially the same function. [W] hen asked whether Glenmark had notified the FDA of these purported inaccurate representations to the FDA, Glenmark's counsel was unaware of such notification. ${ }^{20}$

${ }^{19} I d$.

${ }^{20} I d$. at $1362-63$. 
UCB, Inc. v. Watson Labs. Inc. (2019)

The technology at issue in this decision relates to a transdermal (via the skin) form of delivering a drug that treats Parkinson's disease. ${ }^{21}$ Rotigotine is a drug that has been used since the 1990s for the treatment of Parkinson's disease.

UCB developed a rotigotine transdermal patch without using water and filed the ' 434 patent to cover such a patch. The FDA approved UCB's rotigotine transdermal patches in May 2007, and UCB has been selling the product under the brand name Neupro since July 2007. Neupro's polymer adhesive system is silicone-based.

The only asserted independent claim reads:

1. A transdermal therapeutic system comprising a self-adhesive matrix layer containing the free base [rotigotine] in an amount effective for the treatment of the symptoms of Parkinson's syndrome, wherein the matrix is based on [ ] an acrylatebased or silicone-based polymer adhesive system having a solubility of $\geq 5 \%(\mathrm{w} / \mathrm{w})$ for the free base [rotigotine], all of said free base being present in the matrix in the absence of water; a backing layer inert to the components of the matrix layer; and a protective foil or sheet covering the matrix layer to be removed prior to use.

Actavis filed an Abbreviated New Drug Application (ANDA) for generic versions of transdermal rotigotine patches, and UCB filed suit for infringement of the ' 434 patent under 35 U.S.C. $\S$ 271(e)(2). Actavis's products use a polyisobutylene adhesive, rather than the claimed acrylatebased or silicone-based polymer adhesives, but the district court found the adhesives in this context to be substantially similar and that nothing in this case barred application of the doctrine of equivalents. Actavis did not dispute that its products literally meet every other element of the asserted claims.

On appeal, the Federal Circuit agreed with the district court that UCB was not "barred" from asserting the doctrine of equivalents because of prosecution history estoppel, intentional narrow claiming, vitiation, or ensnarement. ${ }^{22}$

During prosecution of the patent application that resulted in the ' 434 patent, the examiner imposed a restriction requirement. In response, the applicant elected a group of claims that included an "acrylate-based or silicone-based polymer adhesive system" limitation, and the examiner withdrew another group of claims that recited "an adhesive," without specifying any particular adhesive. Actavis argued because UCB withdrew the group of claims that were not limited to silicone- and acrylate-based polymer adhesive systems, it gave up claim scope of adhesives that are not silicates or acrylates and should not be allowed to recapture that subject matter through the doctrine of equivalents.

The Federal Circuit found, however, that:

the examiner's restriction requirement did not relate to polyisobutylene, and the examiner was not communicating anything about the patentability of

${ }^{21}$ UCB, Inc. v. Watson Labs. Inc., 927 F.3d 1272 (Fed. Cir. 2019).

${ }^{22}$ Id. 
polyisobutylene-based adhesive systems. UCB never added a polyisobutyleneexcluding limitation by amendment, and its election cannot be read as such. Moreover, even if UCB had claimed "an adhesive" in the elected claims, as Actavis argues it should have done in order to keep polyisobutylene within the claim scope, the technical differences that triggered the restriction requirement would still have remained and still would have required the same restriction[.] Thus, the restriction requirement here, and UCB's election in response, do not indicate a surrender of polyisobutylene as an equivalent. ${ }^{23}$

The court concluded that UCB had not made a narrowing amendment in respect to the restriction requirement, and accordingly found no good basis in the prosecution history to bar the application of the doctrine of equivalents to polyisobutylene-based polymer adhesive systems.

Relatedly, Actavis argued to the district court that UCB had chosen to draft narrow claims and should not be permitted to expand the scope of those claims through the doctrine of equivalents. Specifically, Actavis argued that Dr. Mueller, an inventor of the '434 patent, knew that polyisobutylene was a polymer that could be used in transdermal patches but chose not to prosecute a claim broad enough to cover polyisobutylene. On appeal, Actavis made the broader argument that polyisobutylenes were generally known in the art, citing Dr. Mueller's knowledge as an example.

The district court disagreed with Actavis, citing the Federal Circuit's holding in Ring \& Pinion Service Inc. v. ARB Corp. that "[t]here is not, nor has there ever been, a foreseeability limitation on the application of the doctrine of equivalents" as to claim limitations that have never been amended or relied on during prosecution, because "[e]xcluding equivalents that were foreseeable at the time of patenting would directly conflict with [prior Supreme Court and Federal Circuit case] holdings that 'known interchangeability' supports infringement under the doctrine of equivalents." 24

On appeal, the Federal Circuit found that, while "Ring \& Pinion does not foreclose consideration of foreseeability of an asserted equivalent as one factor that may, in some cases, help show that the facts cannot support infringement under the doctrine of equivalents," Ring \& Pinion did hold that "foreseeability at the time of claim drafting is not a per se bar to the application of the doctrine of equivalents." 25 In this case, the patent's specification was not shown to rely on or identify any unique characteristics of acrylate or silicone-based polymer adhesive systems that would not be present in a polyisobutylene-based system. The court found the fact that the specification repeatedly recites acrylate- and silicone-based polymers to be irrelevant to the issue of whether it describes those polymers in a manner that would suggest to a skilled artisan that polyisobutylene is not an equivalent. Furthermore, the claims also correspond directly to the specification by reciting all acrylate-based or silicone-based polymer adhesive systems.

Finally, there was no clear evidence that the inventor knew that polyisobutylene is an equivalent. The Federal Circuit found that "there is not enough indication from the patent specification,

${ }^{23} \mathrm{Id}$.

${ }^{24}$ Id., citing Ring \& Pinion, 743 F.3d 831, 834 (Fed. Cir. 2014).

${ }^{25} I d$. 
claims, or the record evidence of the inventor's knowledge here to conclude that UCB surrendered polyisobutylene as a possible equivalent. In the absence of such facts, we agree with the district court that UCB's claiming of acrylates and silicates does not bar treating polyisobutylenes as an equivalent for infringement purposes."

The Federal Circuit went on to note that:

as a policy matter that the patent system should not incentivize inventors to claim equivalents that they had not invented or tested, just because they know of the possibility of an equivalent, and also should not force inventors to delay filing for a patent on what they have invented while testing all known possible equivalents for fear of being unable to assert infringement under the doctrine of equivalents in the future.

Actavis also argued that UCB's doctrine of equivalents infringement theory should fail because it vitiates the "acrylate-based or silicone-base polymer adhesive system" limitation of claim 1 . The Federal Circuit did not agree that finding polyisobutylene to be an equivalent gives the element "an acrylate-based or silicone-based polymer adhesive system" such broad play that the element would disappear entirely. "The district court did not broaden the right to exclude so widely as to cover all adhesive systems and vitiate the 'acrylate-based or silicone-based' claim language." The court also rejected Actavis's argument that a hypothetical claim including polyisobutylenebased polymers would ensnare the prior art.

Moving to the merits, the Federal Circuit found no clear error with the district court's substantive application of the doctrine of equivalents. The district court applied the (in)substantial differences test, under which "[a]n element in the accused device is equivalent to a claim limitation if the only differences between the two are insubstantial." 26 The Federal Circuit has explained that "the substantial differences test may be more suitable ... for determining equivalence in the chemical arts," and identified "structural equivalen[cy]" as particularly relevant when comparing chemical equivalents. ${ }^{27}$

The purpose of the adhesive polymer in the disputed claim element is to act as a scaffold for the drug and to provide adhesion to a patient's skin for the transdermal patch. The district court found that, at the time the ' 434 patent was filed, silicates, acrylates, and polyisobutylenes were the most commonly used pressure-sensitive adhesives in transdermal patches. The district court then identified a set of properties that silicates, acrylates, and polyisobutylenes share: they are pressure-sensitive, adhesive, biologically inert, non-irritating, and non-toxic. Thus, the district court found that a skilled artisan "would recognize that polyisobutylene is not substantially different from the classes of adhesives literally within the scope of the claims."

The district court also made fact findings as to the differences between polyisobutylene and silicates/acrylates. "Polyisobutylene is an organic polymer, consisting exclusively of carbon and hydrogen atoms, forming a non-polar backbone, without any functional groups," and accordingly is non-polar and hydrophobic. Silicates and polyacrylates, unlike polyisobutylene, may contain

${ }^{26}$ Voda v. Cordis Corp., 536 F.3d 1311, 1326 (Fed. Cir. 2008).

${ }^{27}$ Mylan Institutional LLC v. Aurobindo Pharma Ltd., 857 F.3d 858, 869 (Fed. Cir. 2017). 
functional groups that may be polar and/or reactive. So, due to differences in polarity, polyisobutylene has different adhesiveness compared to acrylate- and silicone-based adhesives. Further, polyisobutylene, unlike silicone- or acrylate-based polymers, does not allow for crosslinking agents to be used to increase adhesion or reduce cold-flow. Finally, rotigotine contains atoms that can interact with certain functional groups that can be present in siliconeand acrylate-based polymers, but rotigotine does not interact significantly with polyisobutylene.

The district court went on to explain, however, that these differences do not matter for how the claimed invention works, as evidenced by the comparative results between UCB's Neupro product and the Accused Products, called PIB Neupro (Neupro with polyisobutylene substituted for silicone).

The district court noted that permeation results for Neupro and PIB Neupro were comparable in terms of transdermal delivery of rotigotine at the intended wear time of 24 hours, and that Actavis chose polyisobutylene because it worked just as well as silicone. The district concluded that " $[\mathrm{t}]$ hese results show that the polyisobutylene-based polymer adhesive system did not alter the way rotigotine is transdermally delivered compared to a silicone-based polymer adhesive system," nor did it "alter rotigotine transdermal delivery rates," showing that "polyisobutylene is interchangeable with silicone in the claimed polymer adhesive system." Accordingly, the district court concluded that "[ $\mathrm{t}]$ he polyisobutylene-based adhesive system is an insubstantial modification of the claimed invention."

On appeal, Actavis argues that the district court erroneously relied on evidence comparing UCB's branded Neupro product with (a) Actavis's ANDA product and (b) PIB Neupro. But the district court explicitly stated whether Neupro is or is not an embodiment of the claims is not dispositive of the infringement question because "infringement requires a comparison of the accused product (the ANDA product) and the claims." And the district court only relied on Neupro and PIB Neupro for points unrelated to water content. The district court observed that "[b]oth Neupro itself and the ' 434 patent in exemplary embodiments use silicone adhesives ... that have a solubility for rotigotine of less than $0.1 \%$ " to make the point that the low solubility of polyisobutylene was not a concern that would differentiate it from silicates. The district court also pointed out that Actavis started with Neupro and substituted polyisobutylene for silicone to make PIB Neupro because it viewed the two as interchangeable. And the district court cited the comparative permeation studies because they showed no statistical difference in the amount of rotigotine delivered between the two adhesives. The Federal Circuit found that it was not clear how any of these conclusions are affected by the water content of Neupro, and that, regardless, the district court had many non-Neupro-related reasons for finding substantial similarity here.

The Federal Circuit did not find clear error in any of the district court's fact findings as to polyisobutylene's characteristics as compared to silicates and acrylates. Nor did it find clear error in the district court's fact findings as to what a skilled artisan would have known about the interchangeability of polyisobutylene-based adhesives and silicone-based adhesives (i.e., why the similarities matter more than the differences for the claimed system). Giving credit to those fact findings, it affirmed the district court's conclusion that the claims were infringed under the doctrine of equivalents. 


\section{Eli Lilly \& Co. v. Hospira, Inc. (2019)}

Lilly markets the compound pemetrexed in the form of a disodium salt as Alimta ${ }^{\circledR}$, which is indicated, both alone and in combination with other active agents, for treating certain types of non-small cell lung cancer and mesothelioma. ${ }^{28}$ Pemetrexed is an antifolate, a class of molecules which, at the time of the invention in 2001, was "one of the most thoroughly studied classes of antineoplastic agents."

Three generic companies filed ANDA's seeking approval to market generic versions of Alimta employ a different counterion than Lilly, in particular, tromethamine instead of sodium, i.e, pemetrexed ditromethamine. Lilly sued for infringement of patent claims that recited, inter alia, an "administration of pemetrexed disodium" step. The generic companies use of tromethamine instead of sodium avoided literal infringement, but the district court found infringement under the doctrine equivalents, and the Federal Circuit affirmed.

The defendant generic companies argued that Lilly was precluded by prosecution history estoppel from resort to the doctrine of equivalents, based on an amendment made to the infringed claims during prosecution. As originally filed, the claims broadly recited "administration of an antifolate." The examiner rejected an originally filed claim as anticipated by a reference that disclosed administration of methotrexate (an antifolate). Lilly responded by amending the relevant claims to recite "administration of pemetrexed disodium" rather than "administration of an antifolate," and pointing out that the prior art did not disclose pemetrexed. The rejection with was withdrawn and the claims issued.

The defendants argued that the amendment surrendered antifolates other than pemetrexed disodium. On appeal, Lilly did not dispute that the amendment was both narrowing and made for a substantial reason relating to patentability. However, Lilly argued that the presumption of estoppel created by the narrowing amendment under Festo's tangential exception, i.e., Lilly's amendment narrowing "an antifolate" to "pemetrexed disodium" was only tangential to the accused compound, pemetrexed ditromethamine.

The defendant generic companies argued that Lilly had failed to explain why it did not pursue a narrower amendment literally encompassing pemetrexed ditromethamine, emphasizing the Federal Circuit's statement in previous decisions that the tangential exception is "very narrow." They also pointed out that Lilly cannot be said to have "lacked the words to describe" pemetrexed ditromethamine (quoting Festo II) because Lilly's previous patents, as well as the European companion to the asserted patent, claimed pemetrexed salts generally and pemetrexed disodium in a dependent claim.

The Federal Circuit rejected these arguments, finding the defendants' view of prosecution history estoppel, and the tangential exception in particular, too rigid, noting that "tangential" means "touching lightly or in the most tenuous way." The court found that the reason for Lilly's amendment was to narrow the original claims to avoid prior art that only discloses treatments using methotrexate, a different antifolate.

${ }^{28}$ Eli Lilly \& Co. v. Hospira, Inc., 933 F.3d 1320 (Fed. Cir. 2019). 
To overcome a clear anticipation, Lilly opted to narrow its original claim 2 and its dependents to more accurately define what it actually invented, an improved method of administering pemetrexed. In other words, the particular type of salt to which pemetrexed is complexed relates only tenuously to the reason for the narrowing amendment, which was to avoid [the prior art]. We therefore hold that Lilly's amendment was merely tangential to pemetrexed ditromethamine because the prosecution history, in view of the '209 patent itself, strongly indicates that the reason for the amendment was not to cede other, functionally identical, pemetrexed salts. $^{29}$

The Federal Circuit also rejected the generic companies' suggestion that Lilly must prove that it could not have drafted a claim that literally encompassed pemetrexed ditromethamine, finding the suggestion to be "excessive" and unsupported by precedent, while observing that "[w]e do not demand perfection from patent prosecutors, and neither does the Supreme Court (citing Festo II). Lilly's burden was to show that pemetrexed ditromethamine was 'peripheral, or not directly relevant,' to its amendment, [and] Lilly has done so."

The Federal Circuit also rejected the argument that the disclosure-dedication rule barred Lilly from asserting infringement under the doctrine of equivalents. The patent sets forth its invention as an improved method of administering antifolates, and teaches that the derivatives described in the Akimoto patent are preferred examples of antifolates ${ }^{30}$. A generic company defendant argued that one of these derivatives is pemetrexed ditromethamine and that it was dedicated to the public when Lilly declined to do so. The court disagreed, holding that Lilly's patent does not disclose methods of treatment using pemetrexed ditromethamine, and, as a result, Lilly could not have dedicated such a method to the public.

The court noted that, under Federal Circuit precedent, "[s]ubject matter is considered disclosed when a skilled artisan can understand the unclaimed disclosed teaching upon reading the written description, but not any generic reference necessarily dedicates all members of that particular genus."

Akimoto's formula includes seven functional group variables and encompasses thousands of compounds, and while Akimoto discloses about fifty exemplary compounds, none of them is pemetrexed. Moreover, Akimoto does not even disclose tromethamine expressly but only generically among dozens of other salts. At most, Akimoto discloses ammonium salts generally, which is far from a description of tromethamine. In similar circumstances, we have held that "sufficient description of a genus" requires that a skilled artisan be able to " 'visualize or recognize' the members of the genus." See Ariad Pharm., Inc. v. Eli Lilly \& Co., 598 F.3d 1336, 1350 (Fed. Cir. 2010) (quoting Regents of the Univ. of

\footnotetext{
${ }^{29} I d$.

${ }^{30}$ This is the sentence of the patent disclosure the references the Akimoto patent: "Preferred examples of antifolates include Tomudex ${ }^{\circledR}$, as manufactured by Zeneca; Methotrexate ${ }^{\circledR}$, as manufactured by Lederle; Lometrexol ${ }^{\circledR}$, as manufactured by Tularik; pyrido[2,3-d]pyrimidine derivatives described by Taylor et al in U.S. Pat. Nos. 4,684,653, 4,833,145, 4,902,796, 4,871,743, and 4,882,334; derivatives described by Akimoto in U.S. Pat. No. 4,997,838; thymidylate synthase inhibitors as found in EPO application 239,362; and most preferred, Pemetrexed Disodium (ALIMTA), as manufactured by Eli Lilly \& Co."
} 
Cal. v. Eli Lilly \& Co., 119 F.3d 1559, 1568-69 (Fed. Cir. 1997)). Akimoto does not so describe pemetrexed ditromethamine, and we see no reason why a skilled artisan would set out on [the defendant's] winding path to cobble together pemetrexed ditromethamine. While the '209 patent teaches that pemetrexed disodium is the "most preferred" antifolate, that knowledge would not change the skilled artisan's understanding of what Akimoto discloses. Because Akimoto contains only a "generic reference" to pemetrexed ditromethamine we conclude that it was not dedicated to the public. ${ }^{31}$

Finally, addressing the merits of the doctrine of equivalents analysis, a defendant argued that "the chemical differences between sodium and tromethamine-e.g., $\mathrm{pH}$, buffering capacity, or solubility - render the methods in which each is administered to a patient substantially different." But the Federal Circuit found no clear error in the district court's findings that:

the generic product will accomplish an identical aim, furnishing the same amount of pemetrexed to active sites in the body; in exactly the same way, by diluting a pemetrexed salt in an aqueous solution for intravenous administration. Indeed, after dilution and immediately before administration, DRL's product is functionally identical to Lilly's in that it contains the same amount of diluted pemetrexed anion. ${ }^{32}$

\section{Galderma Labs., L.P. v. Amneal Pharm. LLC (2020)}

The patents at issue in this ANDA action relate to low-dose doxycycline formulations to treat, among other diseases, acne or rosacea. ${ }^{33}$ The patent claims that were found to be infringed under the doctrine equivalents by Amneal's proposed generic product recited compositions of doxycycline having an Immediate Release (IR) component and a Delayed Release (DR) component, combined into one unit for once-daily dosing. Claim 1 of the '740 patent is illustrative:

1. An oral pharmaceutical composition of doxycycline, which at a once-daily dosage will give steady state blood levels of doxycycline of a minimum of 0.1 $\mu \mathrm{g} / \mathrm{ml}$ and a maximum of $1.0 \mu \mathrm{g} / \mathrm{ml}$, the composition consisting of (i) an immediate release (IR) portion comprising $30 \mathrm{mg}$ doxycycline; (ii) a delayed release (DR) portion comprising $10 \mathrm{mg}$ doxycycline; and optionally, (iii) one or more pharmaceutically acceptable excipients.

The doctrine of equivalents issue arose with respect to the "delayed release (DR) portion comprising $10 \mathrm{mg}$ doxycycline." The district court construed the term "delayed release" or "DR" to mean "release of a drug at a time other than immediately following oral administration." The court found no literal infringement, presumably because the accused product lacked a DR portion comprising $10 \mathrm{mg}$ of doxycycline. However, the district court found that Amneal's product contains a DR portion of doxycycline and a separate portion of doxycycline that is not

\footnotetext{
31933 F.3d at 1335.

${ }^{32} \mathrm{Id}$. at $1335-36$.

${ }^{33}$ Galderma Labs., L.P. v. Amneal Pharm. LLC, 806 F. App'x 1007 (Fed. Cir. 2020).
} 
available for release until a time "other than immediately following oral administration," and that these portions together satisfy the DR limitation under the doctrine of equivalents.

On appeal the Federal Circuit affirmed, concluding that the district court had not clearly erred in finding infringement under the doctrine of equivalents. ${ }^{34}$ Amneal's product is manufactured by layering doxycycline in a manner such that doxycycline is released at various intervals. The Federal Circuit explained that, because a portion of the doxycycline is prevented from releasing immediately, the later-releasing portion of doxycycline is released "at a time other than immediately following oral administration." Therefore, this later-releasing portion, "in combination with [the DR portion of doxycycline], is insubstantially different from the [claimed] $10 \mathrm{mg}$ DR portion." Furthermore, the district court concluded that Amneal's product's combination "performs the same function in the same way to achieve the same result as the [claimed] $10 \mathrm{mg}$ DR portion."

The court rejected Amneal's argument that Galderma was precluded from asserting infringement under the doctrine of equivalents due to argument-based estoppel. In particular, during an inter partes review (IPR) of the infringed patent claims, the patent owner sought to distinguish the claimed DR portion over the prior art by arguing that " 'a DR portion' as claimed in the [patent] requires no substantial release from the portion until some time other than promptly after administration - and in particular, until after the DR portion passes through the acidic stomach and sections of the GI tract below pH 4.5." The Board rejected the patent owner's argument and instead agreed with Amneal 'that the broadest reasonable construction of 'delayed release,' in light of the specification of the [patent], is not limited to formulations requiring that there be no substantial release in the stomach." Instead, the Board construed "delayed release" to mean "release of a drug at a time other than immediately following oral administration," i.e., the same construction later adopted by the district court.

The Federal Circuit noted that "statements made by a patent owner during an IPR proceeding can be considered during claim construction and relied upon to support a finding of prosecution disclaimer" so long as the statements are "both clear and unmistakable." The court observed that prosecution disclaimer "promotes the public notice function of the intrinsic evidence and protects the public's reliance on definitive statements made during prosecution," and that the doctrine is rooted in the understanding that "[c]ompetitors are entitled to rely on those representations when determining a course of lawful conduct, such as launching a new product or designing-around a patented invention."

Nonetheless, the court went on to conclude that, because the Board rejected the patent owner's arguments regarding the meaning of delayed release, the record before the Patent Office clearly put the public on notice that the meaning of delayed release with respect to the patents is not limited to formulations requiring that there be no substantial release in the stomach.

While clear and limiting statements made by the patent owner can give rise to disclaimer, they do not in this case where those statements were clearly and expressly rejected by the Patent Office. Because the record makes clear to a skilled

\footnotetext{
${ }^{34} I d$.
} 
artisan that Patent Owner's arguments were rejected, those arguments do not impact claim scope. Accordingly, we see no error in the district court's conclusion that Galderma was not precluded by these statements from asserting the doctrine of equivalents. ${ }^{35}$

\section{Eli Lilly \& Co. v. Apotex, Inc. (2020)}

As discussed previously, Eli Lilly markets pemetrexed disodium (the disodium salt form of the compound pemetrexed) under the trade name ALIMTA ${ }^{\circledR}$. The drug is indicated for use in the treatment of mesothelioma and certain types of lung cancer. Lilly sued Apotex in a HatchWaxman action, alleging that Apotex's proposed generic product infringes a Lilly patent claiming methods of administering pemetrexed disodium to a patient (the same patent at issue in Eli Lilly v. Hospira, discussed above). ${ }^{36}$ Apotex's proposed product contains pemetrexed dipotassium, a different salt form of pemetrexed from pemetrexed disodium, but the district court nonetheless found infringement under the doctrine equivalents. The district court rejected Apotex's argument that infringement under the doctrine equivalents was barred by prosecution history estoppel. In particular, as originally filed the claims specifically recited "ALIMTA," but, in response to an indefiniteness rejection during prosecution, were amended to recite "pemetrexed disodium". Apotex argued that the term "ALIMTA," as used in the patent, refers to "pemetrexed," not limited to any particular counter ion, and thus the amendment was narrowing, thereby triggering prosecution history estoppel. On appeal, the Federal Circuit affirmed, agreeing with the district court that the intrinsic evidence (i.e., the patent specification and prosecution history) clearly specified that "ALIMTA" refers to "pemetrexed disodium," not "pemetrexed" generally, and as such the amendment did not narrow the scope of the claim, rendering prosecution history estoppel inapplicable. ${ }^{37}$

\section{Cases finding patentee likely to succeed under the DOE}

My research also identified the following two Federal Circuit cases, decided in 2005 and 2007, in which the court found, in the context of the appeal of a preliminary injunction, a patentee likely to succeed on an allegation of infringement under the doctrine of equivalents in a HatchWaxman litigation.

Pfizer, Inc. v. Teva Pharm., USA, Inc. (2005)

Quinapril is an angiotensin converting enzyme ("ACE") inhibitor used to treat hypertension. According to the patent at issue in this case, many ACE inhibitors including quinapril are susceptible to degradation due to cyclization, hydrolysis, and oxidation leading to discoloration. ${ }^{38}$ The inventors discovered that cyclization, hydrolysis, and discoloration can be minimized by using formulations containing a metal-containing stabilizer and a saccharide. According to the patent, the metal-containing stabilizer prevents both cyclization and discoloration, while the saccharide prevents hydrolysis. The patent owner, Warner-Lambert, markets a quinapril formulation that employs the patented technology, sold under the trade name

\footnotetext{
${ }^{35} \mathrm{Id}$. at $1010-11$.

${ }^{36}$ Eli Lilly \& Co. v. Apotex, Inc., 2020 WL 7490251.

${ }^{37} \mathrm{Id}$.

${ }^{38}$ Pfizer, Inc. v. Teva Pharm., USA, Inc., 429 F.3d 1364 (Fed. Cir. 2005).
} 
Accupril®. Accupril uses magnesium carbonate and lactose as it metal-containing stabilizer and saccharide, respectively.

Ranbaxy filed an ANDA to bring a generic version of Accupril to market that uses microcrystalline cellulose in place of lactose, thus hoping to avoid a claim limitation that recites "a suitable amount of a saccharide to inhibit hydrolysis." Warner-Lambert sued, and in granting a motion for preliminary injunction the district court found that Warner-Lamber would be likely to establish literal infringement. The court construed "saccharide," as the term is used in the relevant claim, to include "mono- - di-, tri-, and polysaccharides." In doing so, the court rejected Ranbaxy's proposed construction of "sugars, including the lower molecular carbohydrates, specifically mono-and disaccharides." Microcrystalline cellulose is a polysaccharide. The court credited expert testimony presented by Warner-Lambert as providing a persuasive opinion that microcrystalline cellulose does in fact inhibit hydrolysis. The court went on to determine that even if "saccharides" were construed to mean "sugars," WarnerLambert would likely be able to prove infringement under the doctrine of equivalents.

The Federal Circuit affirmed the district court's claim construction and its finding that literal infringement is likely. ${ }^{39}$ And given that this was a motion for preliminary injunction, not a ruling on the merits, the court found it prudent to address the question of infringement under the doctrine of equivalents. The court affirmed, concluding that, based on the totality of the circumstances, even if "saccharides" were construed to mean "sugars," microcrystalline cellulose can be fairly characterized as an insubstantial change from the claimed subject matter without rendering the "saccharide" limitations meaningless. The court noted that it was perfectly appropriate for the district court to credit the testimony of Warner-Lambert's expert, Dr. Brenner, explaining that microcrystalline cellulose does in fact inhibit hydrolysis, and other evidence that microcrystalline cellulose, like sugars, performs the function of inhibiting hydrolysis. The court explained:

Moreover, microcrystalline cellulose, a polysaccharide, is a substance having many monosaccharide units, which are the building blocks of sugars. These similarities convince us that microcrystalline cellulose can be fairly characterized as an insubstantial change when compared to "sugars." Moreover, such a characterization would not render the claim limitations meaningless. Thus, the all limitations rule does not preclude application of the doctrine of equivalents in this case.

Ranbaxy argued that, as a matter of law, microcrystalline cellulose cannot be an equivalent of a "saccharide" because the patentee dedicated microcrystalline cellulose to the public by disclosing, but not claiming, its use in the patent. One alleged disclosure is a listing of "modified cellulose derivatives" as an example of a "disintegrating agent." Another is Example C in the patent, which discloses a prior art composition containing microcrystalline cellulose. The Federal Circuit declined to find that microcrystalline cellulose had been dedicated to the public, holding that "the public notice function of patents suggests that before unclaimed subject matter is deemed to have been dedicated to the public, that unclaimed subject matter must have been

${ }^{39} \mathrm{Id}$. 
identified by the patentee as an alternative to a claim limitation." The court found that even if "saccharides" were construed to mean "sugars," Ranbaxy had not pointed to parts of the patent where the inventors identify microcrystalline cellulose as an unclaimed alternative that would function as a "saccharide" and prevent hydrolysis. The court also rejected Ranbaxy's contention that Warner-Lambert cannot assert that microcrystalline cellulose is an equivalent to the claimed "saccharide" because to do so would impermissibly vitiate the "saccharide" limitation.

Abbott Labs. v. Andrx Pharm., Inc. (2007)

Abbott Laboratories markets an extended-release clarithromycin product, Biaxin XL $®$. Andrx filed an ANDA seeking to market a generic version of the drug, and Abbot sued for infringement of patent claims reciting extended-release formulations comprising an erythromycin derivative (e.g., clarithromycin) combined with a "pharmaceutically acceptable polymer." 40 The "pharmaceutically acceptable polymer" serves as the release-controlling agent for the claimed extended-release clarithromycin compositions. Andrx's product does not contain a polymer, but instead uses glyceryl monostearate ("GMS") as its release-controlling ingredient.

The district court granted a preliminary injunction, based on its conclusion that Abbott had shown a likelihood of proving infringement of the asserted claims under the doctrine of equivalents. The court found that GMS could be functionally equivalent to the required polymer, because GMS performs the same function, in the same way, to achieve the same result as the "pharmaceutically acceptable polymer" in the claims. On appeal, Andrx did not argue that the district court erred in this finding of functional equivalence, and the Federal Circuit affirmed.

\section{Cases finding no infringement under the DOE}

In the following Federal Circuit decisions, the court rejected allegations of infringement under the doctrine of equivalents in Hatch-Waxman lawsuits.

\section{Ortho-McNeil Pharm., Inc. v. Caraco Pharm. Labs., Ltd. (2007)}

Caraco filed an ANDA seeking FDA approval to market a pharmaceutical composition containing tramadol and acetaminophen with an average weight ratio of tramadol to acetaminophen of 1:8.67. Caraco's ANDA expressly requires Caraco's formulation to have a weight ratio of no less than 1:7.5. In response to Caraco's ANDA, Ortho alleged that Caraco infringed claim 6 of the ' 691 patent, which recites "[a pharmaceutical composition comprising a tramadol material and acetaminophen], wherein the ratio of the tramadol material to acetaminophen is a weight ratio of about 1:5."41

The district court construed the term "about $1: 5$ " to mean "approximately $1: 5$, encompassing a range of ratios no greater than 1:3.6 to 1:7.1." Based on this construction, there was no literal infringement, and the district court further found no infringement under the doctrine of equivalents. Relying on the doctrine of claim vitiation, the court concluded that finding

\footnotetext{
${ }^{40}$ Abbott Labs. v. Andrx Pharm., Inc., 473 F.3d 1196 (Fed. Cir. 2007).

${ }^{41}$ Ortho-McNeil Pharm., Inc. v. Caraco Pharm. Labs., Ltd., 476 F.3d 1321 (Fed. Cir. 2007).
} 
infringement by Caraco's formulation with an average weight ratio of 1:8.67 would render meaningless the "about 1:5" limitation.

On appeal, the Federal Circuit found no error in the district court's determination. It found that the 1:5 parameter was critical to the invention, given that the patent disclosed and claimed a number of other ratios and ratio ranges. Furthermore, the patent specification employs $95 \%$ confidence levels, which the court found rendered them relevant to determining the scope of the invention. "An infringement analysis that stretches the bounds of the "about 1:5" limitation beyond those confidence intervals directly conflicts with the patent's express claim to both the $1: 1$ and the $1: 5$ ratios."

Schwarz Pharma, Inc. v. Paddock Labs., Inc. (2007)

Schwarz markets Univasc, a branded drug containing moexipril hydrochloride ("MH"), an ACE inhibitor, as its active ingredient. Schwarz has an exclusive license, with respect to moexipril, under Warner-Lambert's U.S. Patent 4,743,450 ("the '450 patent"). Notes that this is the same patent that the court found likely to be infringed under the doctrine equivalents in Pfizer $v$. Teva by Ranbaxy's generic version of Accupril, as discussed above.

Paddock filed an ANDA for approval to market generic tablets ("the Paddock drug") containing $\mathrm{MH}$ and magnesium oxide ("MgO"). Schwarz sued for infringement of the "450 patent. ${ }^{42}$ The asserted claims recite as one limitation "a suitable amount of an alkali or alkaline earth metal carbonate." $\mathrm{MgO}$ is not an alkali or alkaline earth metal carbonate, i.e., an oxide is not a carbonate, so there was no literal infringement. The district court rejected Schwarz's argument that the Paddock drug infringed under the doctrine equivalents, based on prosecution history estoppel, and on appeal the Federal Circuit affirmed.

The district court determined as a matter of law that arguments made by the inventors and amendments to each of the independent claims made in response to an obviousness rejection did not result in argument-based estoppel, but did result in amendment-based estoppel. Originally, the independent claims recited a "metal containing stabilizer" and "an alkali or alkaline earthmetal salt," respectively, but, following the rejection, each was amended to instead recite "an alkali or alkaline earth metal carbonate." The court held that the change in claim language was a narrowing amendment and presumptively surrendered all metal containing stabilizers and alkali or alkaline earth metal salts except alkali and alkaline earth metal carbonates. The court also held that Schwarz had failed to rebut the presumption of surrender because, magnesium oxide was a foreseeable equivalent of magnesium carbonate and because there was no objectively apparent reason for the narrowing amendment not directly related to the use of magnesium oxide. The court thus concluded that the Paddock drug could not infringe because Schwarz was estopped from claiming that the magnesium oxide used by Paddock was the equivalent of an alkali or alkaline earth metal carbonate.

On appeal, Schwarz argued that estoppel does not apply in this case, as it had never claimed compositions and processes involving $\mathrm{MgO}$, and thus there was no surrender when the claims

\footnotetext{
${ }^{42}$ Schwarz Pharma, Inc. v. Paddock Labs., Inc., 504 F.3d 1371 (Fed. Cir. 2007).
} 
were amended. In support of its argument, Schwarz pointed to the following disclosure in the specification:

The alkaline stabilizers of the invention include the inorganic salts of metals of Groups I and II of the Periodic Table... . The anionic portion of the salt employe[d] may be any which does not deleteriously affect the stability of the overall formulation. Thus, borates, silicates, and carbonates are contemplated.

Schwarz argued that this passage defined "metal containing stabilizer" and "an alkali or alkaline earth-metal salt" such that the anion had to be a borate, silicate, or carbonate, and thus an oxide would not fall within the scope of the original claims, and thus was not surrendered by amendment. But the Federal Circuit disagreed, finding that the specification defined the anion more broadly as "any which does not deleteriously affect the stability of the overall formulation." Borates, silicates, and carbonates were simply listed as examples. There was no dispute that the time the application was filed oxide was a well-known anion for use in pharmaceutical compositions, and that it would not "deleteriously affect the stability of the overall formulation." The court found that since the amendment was made in response to an obviousness rejection by the examiner, it is presumed to have been made for reasons of patentability. Therefore, the court held that the presumption of surrender applies to $\mathrm{MgO}$ because it clearly falls within the territory between the language of the original and the amended claims of the ' 450 patent.

On appeal, Schwarz also argued that even if the presumption of surrender applies, there remained genuine issues of material fact as to whether $\mathrm{MgO}$ was a foreseeable equivalent of an alkali or alkaline earth metal carbonate. Schwarz did not seriously dispute that $\mathrm{MgO}$ was known as a stabilizer by those of skill in the art at the time of the amendment, but rather insisted that $\mathrm{MgO}$ had to have been known as a stabilizer against the specific degradation pathway of cyclization, or for the specific drug category of ACE inhibitors, in order to have been foreseeable as an equivalent. The Federal Circuit disagreed, noting that:

[w] hile care must be taken not to sweep too broadly in defining the field of an invention, Schwarz attempts to define the field of invention too narrowly. The language of original claim 1 (and that of issued claim 1 as well) began with the words "[a] pharmaceutical composition which contains," and the language of a claim defining an invention defines the field within which foreseeability may be considered. The scope of the claim thus supports the district court's treatment of the field of invention as pharmaceutical compositions rather than being limited to pharmaceutical stabilizers that inhibit cyclization in ACE inhibitors. We therefore conclude that, because $\mathrm{MgO}$ was known as a stabilizer in the field of pharmaceutical compositions, Schwarz has failed to rebut the presumption of surrender by demonstrating that $\mathrm{MgO}$ was not a foreseeable equivalent.

Finally, Schwarz also argued that prosecution history estoppel does not apply because the amendment in question bore no more than a tangential relationship to the equivalent in question, viz., $\mathrm{MgO}$. The amendment was made in direct response to an obviousness rejection based on a prior art patent that disclosed the use of magnesium stearate, an alkaline earth metal salt that is not a carbonate, with an ACE inhibitor. The Federal Circuit found that: 
[T] he use of $\mathrm{MgO}$ is directly implicated by the amendment of the claim language at issue because the language amended concerns the types of stabilizers covered by the claims and excludes $\mathrm{MgO}$. The fact that the inventors may have thought after the fact that they could have relied on other distinctions in order to defend their claims is irrelevant and speculative; the inventors chose to distinguish over the [prior art] by narrowing the range of claimed stabilizers to exclude the one disclosed in [the prior art], as well as others. ${ }^{43}$

The court concluded that "the narrowing amendment was directly related to the range of equivalents that Schwarz now seeks to recapture."

Abbott Labs. v. Sandoz, Inc. (2009)

Abbott Laboratories, the patentee in this case, markets crystalline cefdinir under the trade name Omnicef. The FDA approved Lupin's ANDA to market a generic version of Omnicef. Significantly, Lupin's generic product contains almost exclusively the Crystal B form of crystalline cefdinir (cefdinir monohydrate), whereas Abbott's Omnicef product contains the Crystal A form of crystalline cefdinir (cefdinir anhydrate).

Abbot sued for infringement of a patent claiming the Crystal A form of crystalline cefdinir (cefdinir anhydrate). ${ }^{44}$ The district court held that Lupin's Crystal B product did not literally infringe, and did not infringe under the doctrine of equivalents. The Federal Circuit affirmed.

Significantly, the asserted patent claims priority to a Japanese patent application that disclosed and claimed two crystalline forms of cefdinir, "Crystal A" and "Crystal B." Despite using the Japanese application for priority, the U.S. patent's specification only discloses Crystal A, not Crystal B. The court noted that the patent could have claimed the known Crystal B formulation, which was known to the inventors because it appeared in their priority Japanese application. But because they chose not to claim Crystal B, the court held that Crystal B compounds, most relevantly cefdinir monohydrate, fall outside the scope, literal or equivalent, of the asserted claims.

The Federal Circuit explained that:

Abbott cannot extend its exclusive right [] under the doctrine of equivalents to embrace known but unclaimed subject matter. In other words, Abbott effectively disclaimed Crystal B during prosecution of the [U.S.] patent, by removing the Crystal B disclosure from the parent [Japanese] application and emphasizing the sole teaching of Crystal A in communications with the PTO as well as in the [U.S.] specification itself. Abbott cannot now recapture that unclaimed subject matter under the doctrine of equivalents because the Eastern District properly interpreted [the claims] to limit "crystalline" to Crystal A. To expand that claim term to embrace Crystal B would ignore the specific claim limitations of the patent.

Alternatively this court notes that this case seems to fit within the dedication doctrine that forecloses invocation of the doctrine of equivalents. The patent

${ }^{43}$ Id. at $1377-78$.

${ }^{44}$ Abbott Labs. v. Sandoz, Inc., 566 F.3d 1282 (Fed. Cir. 2009). 
applicant clearly knew of the Crystal B forms of the claimed invention because it claimed and disclosed them in its Japanese priority application. Yet it declined to claim an embodiment expressly disclosed in its priority document, thus dedicating that embodiment to the public and foreclosing any recapture under the doctrine of equivalents. See Johnson \& Johnston Assocs. v. R.E. Serv. Co., 285 F.3d 1046, 1054 (Fed.Cir.2002).

The court had this to say about the relationship between "bioequivalency" in the context of a generic drug under Hatch-Waman, and "equivalent" infringement:

Abbott also asserts that Lupin effectively admitted infringement by equivalents when it claimed before the Food and Drug Administration that its cefdinir generic was a bioequivalent to Abbott's Omnicef product. While bioequivalency may be relevant to the function prong of the function-way-result test, bioequivalency and equivalent infringement are different inquiries. Bioequivalency is a regulatory and medical concern aimed at establishing that two compounds are effectively the same for pharmaceutical purposes. In contrast, equivalency for purposes of patent infringement requires an element-by-element comparison of the patent claim and the accused product, requiring not only equivalent function but also equivalent way and result. Different attributes of a given product may thus be relevant to bioequivalency but not equivalent infringement, and vice versa. As the Northern District of Illinois observed in the Sandoz case, "[i]f bioequivalency meant per se infringement, no alternative to a patented medicine could ever be offered to the public during the life of a patent." Sandoz PI Order, 486 F.Supp.2d at 776. Thus, while potentially relevant, the bioequivalency of an accused product with a product produced from the patent at issue is not sufficient to establish infringement by equivalents. ${ }^{45}$

\section{Reckitt Benckiser Inc. v. Watson Labs., Inc. (2011)}

Reckitt obtained FDA approval to market its Mucinex ${ }^{\circledR}$ products, bilayer tablets containing guaifenesin (an expectorant useful for relieving congestion) in both immediate release ("IR") and sustained release ("SR") formulations. Watson filed an ANDA to market its own generic guaifenesin tablet formulations, and Reckitt sued for patent infringement. ${ }^{46}$

The asserted claims recite "A modified release product having two portions, wherein a first portion comprises a first quantity of guaifenesin in an immediate release form which becomes fully bioavailable in the subject's stomach and a second portion comprises a second quantity of guaifenesin in a sustained release form ...."

As originally filed, the application resulting in the patent included claims directed to "[a] sustained release pharmaceutical formulation" and were not limited to a bilayer or two-portion structure. In response to the examiner's rejection of all the original claims for obviousness, the applicants cancelled those claims and added new claims, all of which were directed to "[a] modified release tablet having two portions." In remarks accompanying that amendment, the applicants stated that, to facilitate prosecution, they were relinquishing claims directed to

${ }^{45} \mathrm{Id}$. at 1298 .

${ }^{46}$ Reckitt Benckiser Inc. v. Watson Labs., Inc., 430 F. App'x 871 (Fed. Cir. 2011). 
guaifenesin sustained release (SR) formulations. The applicants also distinguished their new claims over the two cited prior art references, arguing that the new claims, unlike the prior art, required two portions.

Watson's accused products are non-layered polymer matrix tablets made from a single guaifenesin formulation. The district court construed "portion" as "a discrete part of the product," and found that Watson's products do not have separate IR and SR portions, and thus do not literally infringe the patent. The court concluded that during prosecution Reckitt had disclaimed products lacking two discrete structural portions during prosecution of the patent. Further, the court found no infringement under the doctrine of equivalents, because the "two portions" structural limitation is not present in Watson's products, and because Watson's tablets achieve bioavailability in a different way from the claimed tablets.

On appeal, the Federal Circuit affirmed. With regard to the district court's finding of noninfringement under the doctrine of equivalents, the court observed that:

$[\mathrm{O}] \mathrm{n}$ the facts of this case, prosecution history estoppel bars Reckitt from recapturing single-formulation SR guaifenesin tablets like those it disclaimed in obtaining the ' 252 patent. As the district court correctly noted, Reckitt's narrowing claim amendments were made for reasons of patentability. When, in response to an examiner's rejection, a patent applicant submits an amended claim set, the applicant's "decision to forgo an appeal and submit an amended claim is taken as a concession that the invention as patented does not reach as far as the original claim." We, like the district court, take Reckitt's unambiguous prosecution disclaimer as a concession that the asserted claims of the '252 patent do not extend to single-formulation SR tablets such as Watson's accused products. ${ }^{47}$

\section{Duramed Pharm., Inc. v. Paddock Labs., Inc. (2011)}

Conjugated estrogens, used in hormone replacement therapies, are extremely water sensitive and thus highly susceptible to moisture degradation during storage. Duramed developed a

formulation for conjugated estrogens that includes a moisture barrier coating ("MBC") to inhibit the absorption of moisture and reduce storage-related degradation. Duramed filed a patent application with an original claim that recited a conjugated estrogen pharmaceutical composition "coated with a moisture barrier coating." The claim was rejected as obvious, and the Duramed overcame the rejection by amending the claim to recite "a moisture barrier coating comprising ethylcellulose."

Duramed filed suit against Paddock, alleging infringement of the patent based on Paddock's ANDA for a generic version of Duramed's hormone replacement therapy product, Cenestin ${ }^{\circledR} .{ }^{48}$ Paddock's proposed generic product would not literally infringe because it does not include ethylcellulose; instead, its MBC uses a polyvinyl alcohol ("PVA"). Paddock moved for summary judgment of noninfringement, arguing that Duramed was barred by amendment-based prosecution history estoppel from alleging that PVA met the "moisture barrier coating comprising ethylcellulose" limitation of the asserted claims. In its motion for summary

${ }^{47}$ Id. at 878 .

${ }^{48}$ Duramed Pharm., Inc. v. Paddock Labs., Inc., 644 F.3d 1376 (Fed. Cir. 2011). 
judgment, Paddock relied on several pre-amendment references, including an international patent application ("the Colorcon PCT"), published prior to the claim amendment, that discloses formulations of PVA-based MBCs. In a section entitled "Description of the Prior Art," the Colorcon PCT notes several technical drawbacks of using PVA as an MBC.

The district court granted Paddock's motion for summary judgment of noninfringement, holding that prosecution history estoppel barred Duramed's infringement allegations. The district court first held that Duramed's amendment adding the ethylcellulose limitation was substantially related to patentability and narrowed the scope of the asserted claims, thus triggering the presumption under Festo Corp. v. Shoketsu Kinzoku Kogyo Kabushiki Co., 344 F.3d 1359, 136667 (Fed.Cir.2003) (en banc) ("Festo IX"), that Duramed had surrendered all territory between the original and amended claim scope.

The district court then held that Duramed had failed to rebut the Festo presumption based on an argument of, inter alia, the unforeseeability of the use of PVA as an MBC in a pharmaceutical formulation. Rather, the court held that PVA MBCs were foreseeable at the time of Duramed's narrowing amendment, based on the Colorcon PCT's description of PVA as "a moisture barrier coating for pharmaceutical tablets and the like," and its disclosure of the Opadry AMB formulation used in Paddock's proposed generic product. The court rejected Duramed's argument that the Colorcon PCT's disclosure of PVA MBCs' technical drawbacks raised serious questions about PVA's effectiveness as an MBC, concluding that "even if the effectiveness of PVA was unknown in 1998, that would not mean that PVA MBCs were unforeseeable."

On appeal, the Federal Circuit affirmed, holding that Duramed had failed to rebut the presumption of prosecution history estoppel based on unforeseeability. The court noted that,

to the extent that Duramed argues that foreseeability requires that PVA must have been known as an MBC for use with conjugated estrogens, we have previously rejected such a restrictive definition of the field of invention. See Schwarz Pharma, Inc. v. Paddock Labs., Inc., 504 F.3d 1371, 1377 (Fed.Cir.2007). As we spelled out in Schwarz, when the language of both original and issued claims begins with the words "[a] pharmaceutical composition," that language defines the field of the invention for purposes of determining foreseeability. Accordingly, PVA MBCs need only to have been known in the field of pharmaceutical compositions as of the time of Duramed's narrowing amendment, which we hold that the Colorcon PCT establishes as a matter of law. ${ }^{49}$

\section{Spectrum Pharm., Inc. v. Sandoz Inc. (2015)}

The relevant patent claims are directed to a pharmaceutical composition comprising a mixture of $(6 \mathrm{~S})$ and (6R) diastereoisomers of leucovorin, "said composition being of a quantity at least sufficient to provide multiple doses of said mixture of (6S) and (6R) diastereoisomers in an amount of $2000 \mathrm{mg}$ per dose." Leucovorin is a compound used to ameliorate the toxic effects of methotrexate, a chemotherapy treatment ("methotrexate rescue"); to treat folate deficiency; and to enhance the efficacy of a 5-fluorouracil cancer treatment ("5-FU combination therapy").

\footnotetext{
${ }^{49} I d$. ay $1380-81$.
} 
Spectrum, the exclusive licensee of the patent, holds the approved New Drug Application for a levoleucovorin formulation, which it markets under the trade name Fusilev. Sandoz submitted an ANDA seeking approval from the FDA for a drug product that will be imported in the form of single-use vials with $175 \mathrm{mg}$ or $250 \mathrm{mg}$ of levoleucovorin, and Spectrum sued for infringement of the patent. ${ }^{50}$

The district court construed the term "said composition being of a quantity at least sufficient to provide multiple doses of said mixture of (6S) and (6R) diastereoisomers in an amount of 2000 $m g$ per dose" as having its plain and ordinary meaning, which required the composition to contain "enough of the $(6 \mathrm{~S}) /(6 \mathrm{R})$ mixture to provide two or more doses of, at minimum, $2000 \mathrm{mg}$ per dose." After construing the claims, the district court granted Sandoz's motion for summary judgment of noninfringement of claims 5-9. Comparing the product described in Sandoz's ANDA to the claims of the ' 829 patent, the court found that, because the individual vials will contain only up to $250 \mathrm{mg}$ of levoleucovorin, the approved product would not satisfy the claim limitation of at least two doses of $2000 \mathrm{mg}$. The court also rejected Spectrum's argument that an aggregation of Sandoz's approved product - that is, the total amount of levoleucovorin drug product to be imported-would infringe the claims.

The district court further found that Spectrum was precluded from asserting infringement under the doctrine of equivalents because of statements made by the inventors during prosecution. The court cited various instances in the prosecution history in which the applicants had distinguished over the prior art by emphasizing that the application claims (that issued as the asserted claims) had "more stringent quantity limitations" than other application claims lacking that limitation. As a result, the court found "a clear and unmistakable surrender of subject matter covering pharmaceutical composition quantities less than what is required to provide two or more doses of, at minimum, $2000 \mathrm{mg}$ per dose of the mixture."

The Federal Circuit affirmed, holding Spectrum estopped from invoking the doctrine of equivalents by claim amendments and distinguishing statements on the prior art made during prosecution. The court found that:

When submitting an amendment with the application claims that eventually issued as [the claims at issue], the applicants asserted that the newly added claims "include specific limitations as to quantities of materials," and distinguished the prior art by pointing to the "quantities of these specific mixtures specified in the claims." Those claims were also added following an office action rejecting the previous original claims as obvious in view of [the prior art]. The applicants again explicitly highlighted the significance of the dosage limitation during an appeal to the Board, their brief stating that the claims "require a minimum of four grams," the "quantity limitations set forth in the claims" which "define an aspect of the invention that is of great practical significance." The applicants unequivocally argued that [the prior art], which allegedly only produced experimental quantities, "do[es] not teach, suggest, or otherwise render obvious the claimed compositions in the quantity specified" in the application claims that became [the

\footnotetext{
${ }^{50}$ Spectrum Pharm., Inc. v. Sandoz Inc., 802 F.3d 1326 (Fed. Cir. 2015).
} 
claims at issue]. Those statements are clear and unmistakable expressions of the applicants' intent to surrender coverage of quantities of the compound in lower doses. $^{51}$

Indivior Inc. v. Dr. Reddy's Labs., S.A. (2019)

Indivior markets and holds the New Drug Application ("NDA") for Suboxone sublingual film ("Suboxone Film"), an opioid addiction treatment that combines two active ingredients: the opioid buprenorphine and the opioid antagonist naloxone. Suboxone Film is applied below a patient's tongue, where it then rapidly dissolves to release the active ingredients. In 2010, the FDA approved Indivior's film product, the first such product to gain FDA approval. Previously, Indivior sold buprenorphine/naloxone only in a tablet form.

DRL, a generic company, filed an ANDA to market generic versions of Suboxone Film, and was sued by Indivior for allegedly infringing a patent directed to uniform pharmaceutical films. The relevant claims recite a film comprising, inter alia, an active ingredient, $\mathrm{PEO}$, and a hydrophilic cellulosic polymer (HCP). DRL substituted polyvinyl pyrrolidone ("PVP") for HCP in its ANDA product, thus avoiding literal infringement, but Indivior argued that DRL's product infringed under the doctrine of equivalents. The district court held that DRL's product does not infringe under the doctrine of equivalents because the '150 patent disclosed PVP as an alternative to HCP, but did not claim it, thereby dedicating it to the public. ${ }^{52}$

On appeal, Indivior argued that the district court erred in concluding that the disclosurededication rule applied. But the Federal Circuit disagreed, and affirmed. The court found it relevant that:

the patentee claimed a film comprising a polymer component made up of PEO and HCP but disclosed "useful water[-]soluble polymers," including both HCP and other polymers such as PVP. The specification further describes examples of successful films using polymeric blends of PEO and PVP without HCP. These disclosures teach that PVP, an unclaimed embodiment, is an alternative to HCP and thus is dedicated to the public and cannot be recaptured through the doctrine of equivalents. ${ }^{53}$

\section{Amgen Inc. v. Amneal Pharm. LLC (2020)}

Amgen holds an approved New Drug Application for Sensipar, a formulation of cinacalcet hydrochloride used to treat secondary hyperparathyroidism in adult patients with chronic kidney disease who are on dialysis, and to treat hypercalcemia in patients with parathyroid cancer and primary and secondary hyperparathyroidism. Piramal filed an ANDA seeking to enter the market with a generic version of Sensipar, and Amgen brought suit alleging infringement of a patent directed to a rapid dissolution formulation of cinacalcet. ${ }^{54}$

\footnotetext{
${ }^{51} I d$. at 1338 .

52 Indivior Inc. v. Dr. Reddy's Labs., S.A., 930 F.3d 1325 (Fed. Cir. 2019).

${ }^{53} \mathrm{Id}$. at 1347.

${ }^{54}$ Amgen Inc. v. Amneal Pharm. LLC, 945 F.3d 1368 (Fed. Cir. 2020).
} 
As originally filed, the relevant patent claim recited, inter alia, "at least one binder." During prosecution, the Examiner conducted a telephone interview with Amgen's counsel, and Amgen accepted an amendment proposed by the examiner ("Examiner's Amendment"). The Examiner's Amendment revised the "at least one binder" limitation so as to put it in Markush group format. The Examiner then allowed the claims. As amended, the claim recites "at least one binder selected from the group consisting of povidone, hydroxypropyl methylcellulose, hydroxypropyl cellulose, sodium carboxymethylcellulose, and mixtures thereof."

The district court found that Piramal does not infringe because it does not meet the binder limitation. Piramal uses pregelatinized starch. Amgen argued that the cold-water soluble fraction of the starch is equivalent to povidone, a listed binder. The court rejected this argument as barred by prosecution history estoppel. In the court's view, Amgen had narrowed its claims by accepting the Examiner's Amendment to exclude binders different from those listed in the Markush group.

On appeal, Amgen first argued that the presumption of estoppel does not apply here because it did not narrow the binder or disintegrant limitations for reasons of patentability. Amgen points to the absence of any statements by the Examiner about the Markush groups in particular and Amgen's own later statement in a second Request for Continued Examination that the language added by the Examiner was not added in "response to a prior art rejection but rather to place the claims in proper format and to better define the claimed subject matter, including equivalents."

Amgen further argued that, even if the presumption of estoppel applies, it had been overcome because the Markush limitations were added for reasons other than patentability. Amgen argued that the Examiner's Amendment simply explained in more explicit terms and clarified the composition that the claims already covered. Because the Markush groups and treatment limitations were already present in previously rejected dependent claims, Amgen argued that a person of skill would have understood from the intrinsic record that the Examiner's Amendment was not related to patentability.

The Federal Circuit disagreed, however, and found Amgen's doctrine of equivalents argument barred by prosecution history estoppel. The court found Amgen's reading of the prosecution history, under which the Examiner proposed the Examiner's Amendment for no purpose at all, "at best unpersuasive."

The court further noted that Amgen's statement in its second Request for Continued Examination that the Examiner's Amendment was added "to place the claims in proper format and to better define the claimed subject matter," was made over eight months after the Examiner's Amendment was accepted and the claims were allowed. Thus, it was "unclear what, if any, insight this conventional boilerplate statement provides into the reasons for the Examiner's Amendment."

Eagle Pharm. Inc. v. Slayback Pharma LLC (2020)

Eagle Pharmaceuticals Inc. ("Eagle") markets a branded bendamustine product, BELRAPZO, for use in the treatment of chronic lymphocytic leukemia and indolent B-cell non-Hodgkin 
lymphoma. Slayback Pharma LLC ("Slayback") filed a new drug application ("NDA") for a generic version of BELRAPZO, and Eagle sued for patent infringement. ${ }^{55}$

The asserted claims recite a non-aqueous liquid composition comprising, inter alia, bendamustine and a "pharmaceutically acceptable fluid comprising a mixture of polyethylene glycol and propylene glycol." Slayback's product does not contain propylene glycol ("PG"), but it does contain ethanol, which Eagle argued is insubstantially different from the PG in the claimed composition, and thus Slayback's product infringes the "pharmaceutically acceptable fluid" limitation under the doctrine of equivalents.

The district court entered a judgment of non-infringement on the pleadings. The court determined that the written description of the asserted patents unambiguously and repeatedly identifies ethanol as an alternative to PG. For example, the Summary of the Invention discloses that:

In other aspects of the invention, the bendamustine-containing compositions include a) a pharmaceutically acceptable fluid which contains one or more of propylene glycol, ethanol, polyethylene glycol, benzyl alcohol and glycofurol, and b) a stabilizing amount of a chloride salt.

Likewise, the specification teaches that:

Preferred pharmaceutically acceptable fluids include PG, PEG or ethanol in this embodiment of the invention.

The district court concluded that it had "sufficient context to decide a question of law-i.e., that the disclosure-dedication doctrine applies to bar Eagle's claims for infringement under the doctrine of equivalents.

On appeal, Eagle argued that the disclosure-dedication doctrine does not apply because the asserted patents do not disclose ethanol as an alternative to PG for the claimed embodiment containing an antioxidant. Eagle contended that the asserted patents disclose three distinct "categories" of bendamustine formulations: (i) chloride salt formulations; (ii) antioxidant formulations; and (iii) dimethyl sulfoxide ("DMSO") formulations. According to Eagle, a skilled artisan would recognize that the three separate categories "have separate ingredients[ ] and work in different ways." Eagle asserted that the specification only discloses ethanol as an alternative to PG when discussing the unclaimed chloride salt formulations; it never discloses ethanol as an alternative to PG when discussing the claimed antioxidant formulations. As a result, Eagle concludes, a "skilled artisan would not understand that ethanol ... is an alternative to PG in the separate, claimed 'PEG/PG/antioxidant' category of formulations."

The Federal Circuit disagreed, holding that the disclosure-dedication doctrine does not require the specification to disclose the allegedly dedicated subject matter in an embodiment that exactly matches the claimed embodiment. Instead, the disclosure-dedication doctrine requires only that

\footnotetext{
${ }^{55}$ Eagle Pharm. Inc. v. Slayback Pharma LLC, 958 F.3d 1171 (Fed. Cir. 2020).
} 
the specification disclose the unclaimed matter "as an alternative to the relevant claim limitation."

The Federal Circuit concluded that:

the asserted patents disclose ethanol as an alternative to PG in the "pharmaceutically acceptable fluid" claim limitation. The specification repeatedly identifies - without qualification-ethanol as an alternative pharmaceutically acceptable fluid. Aside from the description of certain exemplary embodiments, nothing in the specification suggests that these repeated disclosures of ethanol are limited to certain formulations, or that they do not extend to the claimed formulation. ${ }^{56}$

The Federal Circuit distinguished over its holding in Pfizer, explaining that in Pfizer:

the claim limitation-at-issue recited a specific purpose: "a suitable amount of a saccharide to inhibit hydrolysis." The asserted alternative, microcrystalline cellulose, was disclosed in the specification without any relation to hydrolysis. As a result, we were "not convinced that one of ordinary skill in the art would come to the conclusion that the inventors have identified microcrystalline cellulose in that formulation as an alternative to a 'saccharide' that prevents hydrolysis."

In this case, the claim limitation-at-issue has only one stated purpose: that the fluid be "pharmaceutically acceptable." Unlike in Pfizer, the specification here repeatedly discloses ethanol as serving that purpose, i.e., the specification expressly discloses ethanol as a "pharmaceutically acceptable fluid." We therefore hold that the asserted patents dedicated ethanol to the public by disclosing, but not claiming, ethanol as an alternative to PG in the "pharmaceutically acceptable solvent" claim limitation. ${ }^{57}$

\section{Conclusion}

This comprehensive look at the small subset of Federal Circuit decisions in which the doctrine of equivalents is asserted in the context of Hatch-Waxman litigation supports Kevin Noonan's observation that, indeed, the doctrine is experiencing a marked resurgence at the Federal Circuit. The doctrine never went away entirely, with Hatch-Waxman decisions in 2005, 2006, and 2007 either affirming a finding of infringement under the doctrine of equivalents or, in the context of a grant of preliminary injunction, finding the patent owner likely to prevail on a theory of infringement under the doctrine. But a review of recent case law suggests that today's Federal Circuit has become more receptive to allegations of infringement under the doctrine, and less likely to find the doctrine barred by prosecution history estoppel than was the case in the years immediately following the Festo decisions. In particular, my search (conducted on Westlaw) going back to 2005 found four decisions in 2019 and 2020 in which a branded drug company prevailed under a theory of doctrine equivalents. In contrast, I only found a total four such decisions in the 2005-2018 timeframe.

${ }^{56} \mathrm{Id}$. at 1176 .

${ }^{57} I d$. at $1176-77$. 


\section{PRE-PRINT VERSION}

Clearly, reports of the doctrine of equivalents' demise were premature, and it remains a viable means for branded drug companies to block market entry by generic competitors that manage to avoid literal infringement of Orange book-listed patents. 